\title{
Geographic distribution and conservation status of Caiman latirostris (Crocodylia, Alligatoridae) in Uruguay
}

\author{
Claudio Borteiro', Carlos Prigioni², José Eduardo García ${ }^{3}$, Marcelo Tedros ${ }^{4}$, \\ Francisco Gutiérrez ${ }^{5}$, and Francisco Kolenc ${ }^{6}$ \\ 1 Río de Janeiro 4058, CP 12800, Montevideo, Uruguay. E-mail: borteiro@adinet.com.uy. \\ 2 Secretaría de Medio Ambiente, Intendencia Municipal de Treinta y Tres, Uruguay. E-mail: cprigioni3@yahoo.com.ar. \\ 3 Dirección General de Aduanas, La Coronilla, Rocha, Uruguay. \\ ${ }^{4}$ China 2202, CP 12800, Montevideo, Uruguay. \\ 519 de Abril 3490, CP 11700, Montevideo, Uruguay. \\ ${ }^{6}$ Universidad de la República, Universidad Católica, Montevideo, Uruguay.
}

\begin{abstract}
Geographic distribution and conservation status of Caiman latirostris (Crocodylia, Alligatoridae) in Uruguay. Populations of Caiman latirostris are known to occur in Uruguay but their geographic distribution remains uncertain. This work presents an update of the species distribution and conservation status in Uruguay. Surveys conducted by the authors confirmed the presence of this species in the previously known distribution range of northwestern Uruguay, where it seems to be widespread and relatively abundant in contrast to earlier reports. We report new localities for $C$. latirostris, most relevant being those of the Cebollatí and Tacuarí Rivers, and the Pelotas, India Muerta and San Miguel stream basins, which significantly expand its distribution through important wetlands in the eastern part of the country. The overall distribution is coincident with different landscape types, where lagoons, artificial impoundments, livestock waterholes, rivers, streams, creeks and marshes are inhabited by caiman. Illegal non-commercial hunting was detected all over the country.
\end{abstract}

Keywords: Crocodylia, Alligatoridae, Caiman latirostris, Broad-snouted Caiman, distribution, conservation status, Uruguay.

\section{Introduction}

The Order Crocodylia is widely distributed through tropical and subtropical areas around the world (Sill 1968), with the largest popula-

Received 18 April 2006.

Accepted 1 November 2006.

Distributed December 2006. tions and the highest number of species occurring in the Neotropical Region (Ross 1998). Caiman latirostris (Broad-snouted Caiman) is the crocodilian that reaches the southernmost distribution among neotropical species (Brazaitis 1973). This caiman, native to Argentina, Brazil, Bolivia, Paraguay and Uruguay, spreads over the Paraná, Paraguay, São Francisco and Uruguay river basins, and coastal Atlantic drainages from northeastern 
Brazil to southern Uruguay (Achaval and San Martín 1983, Verdade 1998, 2001). The knowledge of $C$. latirostris biology in the wild comes mainly from the southern areas of its range distribution and is limited to a few studies about ecology in Brazil (Diefenbach 1979, 1988, Melo 2002, Verdade et al. 2002) and about nesting in Argentina (Larriera 1995, Piña et al. 2002) and Uruguay (Achaval and González 1983, Vaz-Ferreira and Achaval 1986, González 1987). It is the only caiman species present in Uruguay, where very little information is available and its local geographic distribution has been reported inaccurately (Medem 1983, Yanosky 1990, Verdade 1998). Uruguayan populations are known mainly from northern Uruguay, in the Cuareim and Uruguay River tributaries, and a few specimens have had been reported from other areas (Achaval and San Martín 1983, Achaval 1997, 2001). The purpose of this study was to update the distribution of $C$. latirostris in Uruguay based on field surveys in the northern and eastern regions of the country and to discuss its current local conservation status.

\section{Material and Methods}

Information about geographic distribution of C. latirostris in Uruguay was obtained from three different sources: published reports with references to localities from where eggs, juvenile and adult specimens were seen or collected, field surveys carried out by the authors between 1981 and 2003 in northern and eastern Uruguay, and information given by local people at visited sites. Although reports provided by local people often lack objectivity and replicability, selected information was included where complementary data were obtained (Magnusson 1982).

Different survey methods were used. In northern Uruguay at the Department of Artigas caiman were sighted during spot-light counts as part of a monitoring protocol (Borteiro 2005), and in the rest of the country surveys were diurnal and on foot. When caiman were approachable enough to determine and to estimate total length (TL) from head length (Magnusson 1983), individuals were assigned to size categories following Velasco and Ayarzagüena (1995): juveniles (up to $49 \mathrm{~cm}$ ), subadults $(50-119 \mathrm{~cm})$, adults $(>120 \mathrm{~cm})$. Specimens in which size estimates were not determined were included in the "eyes only" category (EO) (Bayliss 1987).

\section{Results}

\section{Literature Data}

The first reference to the distribution of Caiman latirostris in Uruguay is the work of Vaz-Ferreira and Sierra (1960), which gives a morphological characterization of Uruguayan specimens. Localities mentioned by these authors were included in the list in which Achaval (1997) summarized data of specimens collected in Uruguay between 1945 and 1995; these specimens are deposited in the Reptile Collection of the Zoology Department of the Facultad de Ciencias, Uruguay (ZVCR), and in the Museo Nacional de Historia Natural of Montevideo (MNHN). Most specimens came from the Uruguay River basin in northwestern Uruguay, at the Departments of Artigas and Salto. Their respective localities are shown in Figure 1 and listed below (numbers between square brackets) along with the collection date(s): [1] Itapebí stream (1957), [2] El Espinillar stream (1957, 1982, 1995), [3] Arapey Grande River (1972), [4] Colonia Lavalleja (1990), [5] Yacuy stream, [6] Zapallo Island (1980), [7] Colonia Palma (1991), [8] Bella Unión (1964, 1967), [9] Yucutujá stream (1952), [10] Tres Cruces Grande stream (1980), [11] Yacaré stream (1952), [12] Yacot stream (1954), [13] Yuquerí (1970), [14] Cuaró Chico stream (1991), and [15] Tres Cruces Chico stream (1958).

According to Achaval (1997) one specimen was collected on the Queguay River, northern Uruguay, at Dept. of Paysandú (ZVCR 189, 

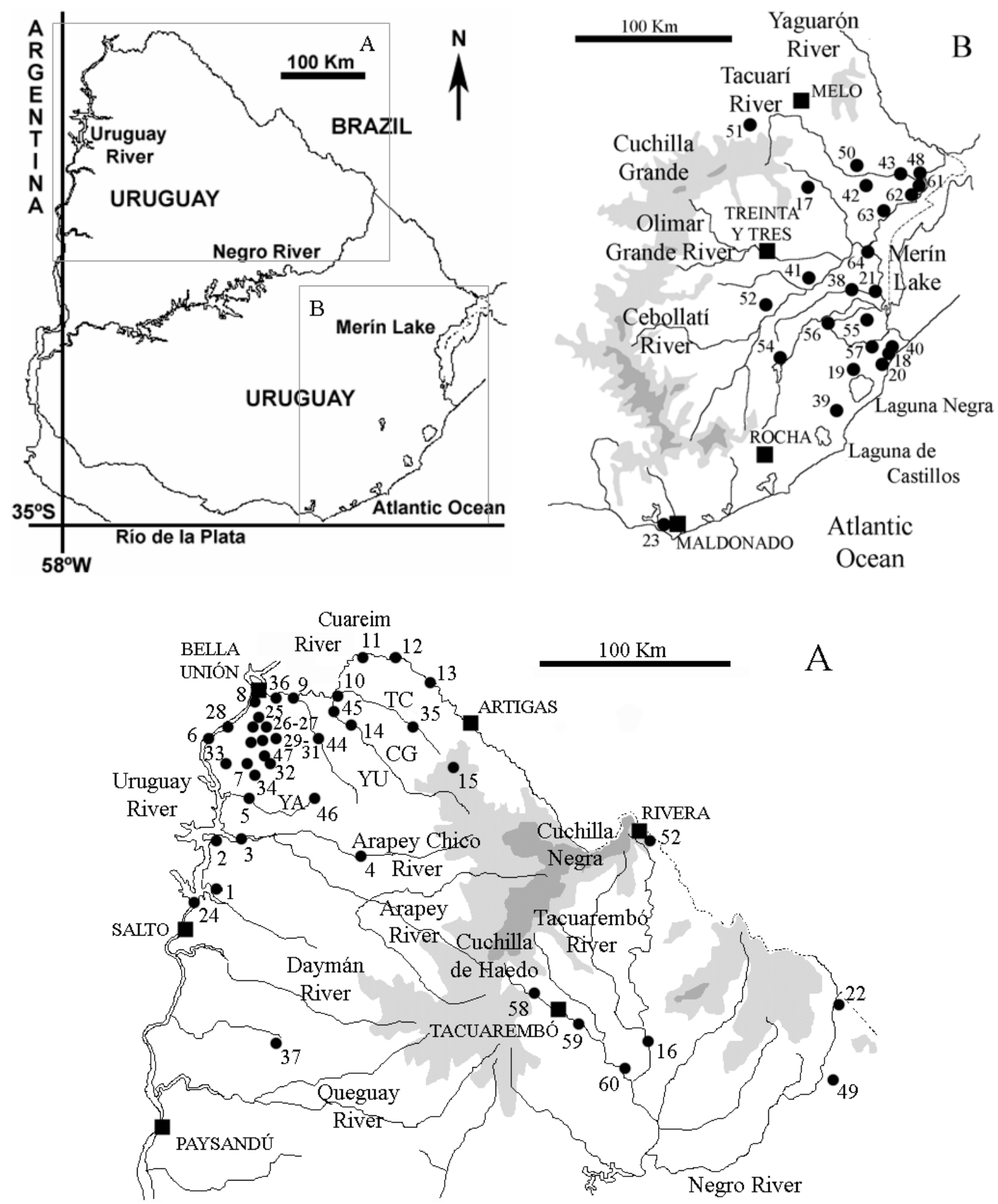

Figure 1 - Distribution of Caiman latirostris in (A) northern and (B) eastern Uruguay. Dots indicate known localities, numbered as in the text. Shaded areas indicate altitudes between 100-200 m and above $200 \mathrm{~m}$ a.s.l. (grey and dark grey, respectively). Squares are major human settlements (more than 10,000 inhabitants). Abbreviations: CG, Cuaró Grande stream; TC, Tres Cruces Grande stream; YA, Yacuy stream; YU, Yucutujá stream. 
1952), but exact locality is not given. The same author mentioned four other specimens coming from middle and eastern Uruguay that were collected at Pueblo Ansina [16], in the Tacuarembó River, Dept. of Tacuarembó (MNHN 2021, March 1974), Leoncho stream [17] at the Dept. of Treinta y Tres (MNHN 1958, 1959), and at Estero del Escudero [18] (ZVCR 3944, December 1971) and Bañado de Santa Teresa [19] (ZVCR 4097, 1 August 1978), Dept. of Rocha. Specimens ZVCR 3944 and ZVCR 4097 and two other adults, one of them from $\mathrm{La}$ Coronilla [20], are the first records of $C$. latirostris in southeastern Uruguay in recent times (Achaval and San Martín 1983). Another report from eastern Uruguay mentioned caiman poaching in the Pelotas stream basin, in the Dept. of Treinta y Tres [21], in 1985 and 1998 (PROBIDES 2001). There are two other references to the presence of caiman in this part of the country in historical times, the oldest one is the report of an accident in which a caiman killed a soldier who was having a bath in a river near Aceguá, Dept. of Cerro Largo [22], close to the border with Brazil, on 18 January 1827 (Brito del Pino 1956: 64); the other one is a newspaper article about a caiman that was killed but not preserved in 1891, at the coastal lagoon Laguna del Diario [23], at the Dept. of Maldonado (Anonymous 1891). The presence of caiman at Salto Grande Hydroelectric Dam in the Uruguay River [24] was reported by Achaval (1977) without further details.

Localities where C. latirostris eggs were collected in Uruguay are given below according to Achaval and San Martín (1983), Vaz-Ferreira and Achaval (1986) and Achaval (1997), indicating the date of collection: Puerto Pedregullo (1945); Yacaré stream (25 January 1952); Tres Cruces Grande stream (1 March 1954); Zapallo Island [6], a nest with eggs in early developmental stage was found (14 January 1980); Espinillar lagoon (22 October 1982) and El Espinillar [2], where a female (ZVCR 5117) was collected while tending her nest (26 January 1995); and Arapey River [3], where a nest almost ready to hatch was collected (14 March 1972). González (1987) collected two nests in late incubation period at Naquiñá stream, Dept. of Artigas, on 13 March 1987, but neither exact locality nor reference material were mentioned. All these references about caiman nesting belong to the Uruguay River basin in northwestern Uruguay (Figure 1).

\section{Field Surveys}

During this study we surveyed extensive areas of the Depts. of Artigas, Paysandú, Rivera and Tacuarembó in northern Uruguay, and of the Depts. of Cerro Largo, Treinta y Tres and Rocha in eastern part of the country. In northern Uruguay spot-light surveys in agriculture impoundments, streams, and the Uruguay River were done by boat, and in other habitats, such as livestock waterholes, creeks, marshes and riverine forests, surveys were done on foot. Nests were located by searches on foot during daylight.

At the Dept. of Artigas we observed caiman in several new localities at tributaries of the Uruguay and Cuareim Rivers, which are listed below (Figure 1). A nest apparently hatched was found on 14 January 1999 at the Itacumbú stream [25], adjacent to an agriculture impoundment in which we also observed nine EO. Another two EO were observed at the same site in marshes satellite to the main course of the stream on 17 January 2002. In the surroundings of Calpica [26], a nest was found hatched on 26 February 1999 on an artificial dam parallel to the Lenguazo stream course. Nearby, five subadults, two adults and one EO were observed in an agriculture impoundment [27] on 12 January 2003. At Copcabu [28] in the Ñaquiñá stream basin, three nests destroyed by predators were found, two of them on a creek (16 January 1999) and another one by an agriculture impoundment built on floating vegetation (20 February 2003). At Lagreca Establishment [29], in the Ñaquiñá stream basin, one adult and three EO were observed in an agriculture impoundment on 14 
December 2001, and a nest in late incubation period was found on grasslands close to a creek in February 2001. Close to this locality, at Los Espinillos Establishment [30], a nest was found on 15 January 2002 into the shoreline forest of a creek. This nest was hatched by 16 March. At this site 16 sub-adults, one adult and 14 EO were observed in an agriculture impoundment on 12 December 2001. Also in the Ñaquiñá stream basin we surveyed agriculture impoundments on small creeks at Colonia Viñar [31], where six juveniles, seven sub-adults and one EO were observed on 12 January 2003. A bit more southwards, at Falso Mandiyú stream [32], three nests were found on agriculture impoundments, two of them taken by humans (16 January 1999, 23 March 2001). Three subadults, seven adults and two EO were also seen in another agriculture impoundment along this stream on 12 March 2002. On a livestock waterhole at Tigre stream [33], close to the Uruguay River, a sub-adult and a female tending her nest, which was in late incubation period, were observed on 26 March 2001. At the Guaviyú stream [34], we observed an adult on 19 February 2003, hidden at the shoreline into the riverine forest. At the locality of Colonia Javier de Viana [35], we located a nest destroyed by humans into the forest of a lagoon satellite to the main course of Tres Cruces Grande stream, on 28 February 1999. In a survey done at Pay Paso Establishment [36] we observed an adult in a lagoon close to the Cuareim River, and at the Zapallo Island on the Uruguay River [6] one EO was seen on 15 March 2002. At the Department of Paysandú we surveyed creeks of the Tierras Coloradas stream basin [37] on 22 March 1997, where we observed two sub-adults.

In eastern Uruguay we visited previously known localities of $C$. latirostris and several new ones were found, mainly at the Depts. of Rocha and Treinta y Tres. New localities of the Dept. of Rocha are Estero de Pelotas [38], where two adults were seen in marshy habitat; Paso del Bañado [39], where one adult was seen on January 1981, and El Porvenir Establishment [40], in the surroundings of La Coronilla. At this last site we captured an adult of 2,15 m TL. We visited the previously known localities of La Coronilla [20], and Bañado de Santa Teresa [19]. A male of 2,3 m TL killed by hunters was collected by one of us (JEG), J. E. García (Jr.) and $M$. Terra in the first (ZVCR 5472, November 1994), and one adult and two subadults were seen in a cattle waterhole in the latter (12 October; 15, 22, and 29 December 2002).

At the Dept. of Treinta y Tres we recorded caiman presence in the following new localities: Arrayanes del Cebollatí [41], one adult was seen in the Cebollatí River on 20 November 2002; Tacuarí River, one adult was observed at Kiosco Tacuarí [42] on 30 May 2003, and one sub-adult and two adults were observed a bit more westwards [43] in October 2002.

\section{Records Based on Information from Local People}

We selected information about new localities of C. latirostris obtained from local people during surveys in different areas. In many cases we confirmed caiman presence as we observed photographs or even rests of poached specimens. At the Dept. of Artigas these new localities are: Yucutujá Miní [44] (28 January 1999), Cuaró Grande [45] (February 1999), Yacuy [46] (January 2002), and Mandiyú streams [47] (January 2003). At the Dept. of Tacuarembó, local people were aware of the presence of adult caiman in the Tacuarembó River at the localities of Zapará [58], Paso Bonilla [59] (January 2003) and Las Veras [60] (1998). Also in northern Uruguay, an adult was known to inhabit a cattle waterhole at Cerro Trindade [53], $20 \mathrm{~km} \mathrm{E}$ of the city of Rivera, Dept. of Rivera (April 1992).

In eastern Uruguay we recorded reports of caiman presence at the Depts. of Cerro Largo, Lavalleja, Rocha, and Treinta y Tres. At Cerro Largo we observed photographs of an adult 
caiman killed by hunters on December 1996 in marshes south to Balneario Laguna Merín [48], and we obtained rests of an adult killed by hunters on May 2005 in marshes of the Fraile Muerto stream basin [51]. Other new localities in Cerro Largo are Pantanoso [49] (1988) and Yacaré lagoon [50] in the Mangrullo stream basin. At the Dept. of Lavalleja a basking adult was seen from an aircraft, in marshes SE of José Pedro Varela [52] on 2 April 2003. At the Dept. of Rocha we observed a preserved skull and skin of an adult killed by hunters in 1970 at Bañados de India Muerta [54]. Rural people of Rocha mentioned the presence of two adults at San Luis, in the San Luis River basin [55], and of another adults at $\mathrm{Km} 324$ of Route 14 [56] (2001) and in marshes of the San Miguel stream [57] (12 Apr. 2003). Other localities of this area in which local people mentioned the presence of caiman were La Coronilla [20] (December 1992), Uriarte Establishment [18] close to Estero del Escudero (January 1993), and Arrozal Saglia [64], where an adult was seen in 1998. At the Dept. of Treinta y Tres we were told about caiman sightings at two localities over the Tacuarí River, one of them close to the Merín Lake [61] (October 2002), and the other approximately $15 \mathrm{~km} \mathrm{~W}$ of Paso del Dragón [62], where a nest in riverine forest was apparently destroyed by predators (December 2002). Local people also said that caiman were present in marshes of the Zapata stream [63], in the Merín Lake basin (April 2003).

Geographic coordinates of visited sites are given in Appendix I. Illegal hunting was detected in virtually all these sites. It was noticed that hunters shoot basking caiman or at night by shining their eyes. Sometimes baited hooks, sticks or bones were also used. The bait commonly used was cattle or sheep lung ("bofe") as it floated in water, the line attached to the hook, bone or stick, usually anchored to something on the shoreline. In the Dept. of Artigas, local people and hunters usually eat $C$. latirostris meat.

\section{Discussion}

The localities we surveyed in northern Uruguay do not significantly extend the previously known distribution of Caiman latirostris in this area (Achaval 1997, 2001), but confirmed its continued presence at those sites where specimens were collected almost fifty years ago. It is noteworthy that the Broadsnouted Caiman is a common species in the Depts. of Artigas and Salto, and widespread and abundant in the tributaries of the Cuareim and Uruguay Rivers. Our findings are in contrast with earlier local reports about the species conservation status in the area.

Observations on $C$. latirostris in eastern Uruguay were sporadic in the last 25 years and few specimens were collected (Achaval and San Martín 1983, Achaval 1997). Achaval (1980) also mentioned the presence of caiman at the Dept. of Cerro Largo without giving localities. We believe, as did Medem (1983), that the scarcity of records for the species in this region is because of the lack of fieldwork. Our surveys added new locations for the Depts. of Rocha, Tacuarembó and Treinta y Tres, and the first for Cerro Largo and Rivera in recent times. These observations extend the known distribution of $C$. latirostris considerably. We found that $C$. latirostris is more common and widely distributed in central and eastern Uruguay than was previously assumed, for a region with important areas of fluvial plains that appeared suitable for caiman populations to be resident (Medem 1983). However, we did not confirm nesting in this area. The accident mentioned by Brito del Pino (1956) in Cerro Largo close to the border with Brazil is one of the few reported fatal attacks on humans by the Broad-snouted Caiman (Yanosky 1990).

The new record we reported here for Paysandú (Tierras Coloradas stream basin, $31^{\circ} \mathrm{S}$ ) is the southernmost known locality of the species distribution in the Uruguay River basin, but it probably ranges farther south. The southern extent of the species range in western Uruguay 
is still unclear. Orejas-Miranda (1969) mentioned that $C$. latirostris is present in the Depts. of Artigas, Salto and Paysandú but did not give any details. Talice (1971) stated that the species was restricted to Artigas and northern Salto, and that in the past it could be found in Paysandú, suggesting a range reduction caused by illegal hunting. In Argentina, C. latirostris can be found to $32^{\circ} \mathrm{S}$ in the Paraná River basin, in Entre Ríos and Santa Fe Provinces (Freiberg and Leitão de Carvalho 1965, Venturino 1994, Waller and Micucci 1994). During extraordinary episodes of flooding, individuals are transported to higher latitudes (Micucci and Waller 1995), occasionally reaching the Río de la Plata (Chebez et al. 1994). The presence of caiman over the eastern Atlantic coastal drainage in Uruguay at more southern latitudes than in the Uruguay River basin $\left(34^{\circ} \mathrm{S}\right)$ may be possible by microclimatic conditions found in the vast wetlands of the Depts. of Rocha and Treinta y Tres. Wetland microclimatic factors were suggested as responsible for the occurrence of the southernmost populations of Caiman yacare in the Iberá and Paraná River hydrographic systems of Corrientes Province, Argentina (Micucci and Waller 1995). The report of C. latirostris for the Dept. of Maldonado (Laguna del Diario) reflects an extended presence of the species through the system of coastal Atlantic Lakes ("Lagunas Litorales”) in historical times.

Known localities of Caiman latirostris in Uruguay present an interesting distribution pattern, as they are distributed over four distinctive hydrographic systems, which according to Praderi and Vivo (1975) are: 1) the Uruguay River basin in the northern part of the country, 2) the Tacuarembó River and upper Negro River, 3) the Merín Lake basin, and 4) the eastern coastal Atlantic drainage. The populations of Broad-snouted Caiman in northwestern Uruguay at the Depts. of Artigas, Salto and Paysandú are connected through the Uruguay River basin with Argentine populations in Corrientes, and Entre Ríos Provinces, and also with Brazilian populations of western Rio
Grande do Sul state. The Cuchilla de Haedo and Cuchilla Grande formations possibly are not important geographic barriers for this species as it is known to colonize topographically elevated habitats (Morato 1991), but valleys and rocky hills are probably not suitable environments (Evia and Gudynas 2000). The Negro River could be a corridor connecting the northwestern and eastern populations of the species in Uruguay, but the impact of the three hydroelectric dams built in this river is still unknown. Populations of the Merín Lake basin and the Atlantic drainage in Uruguay are very close to those of southeastern Rio Grande do Sul, and are probably more related to them. The closest localities reported in Rio Grande do Sul state are Lagoa dos Patos (Diefenbach 1988) and Reserva Ecológica do Taim (Melo 2002), but the presence of the species in Barra do Chui at the border with Uruguay and farther north seems to be rather common (JEG, pers. obs.).

The distribution area of $C$. latirostris in Uruguay occurs in five different landscape units, described by Evia and Gudynas (2000). One is the "Praderas" (grasslands) landscape, mainly used for cattle production. It is composed of smooth-hilled lowlands covered by natural grasslands, with small patches of natural forests and marshes associated with rivers and streams. Another landscape unit is "Planicies fluviales" (fluvial plains) characterized by marshy habitats, riverside natural forests and lagoons adjacent to lothic water bodies. The most important ones with caiman populations in Uruguay are those of the Arapey, Cebollatí, Cuareim, Guaviyú, Negro, Tacuarembó and Uruguay Rivers. A third important landscape unit is "Litoral Sur Oeste", a highly modified and heterogeneous area because of agricultural activities over the fluvial plain of the Uruguay River. The landscape here is a mixture of crops, cattle production, natural grasslands, small marshes, and remnants of gallery forests. Although anthropic modifications are important in this last landscape unit, caiman are particularly abundant (Borteiro 2005). The other two landscape units with 
caiman populations are "Grandes Lagunas Litorales” (great Atlantic coastal lakes) and "Planicies del Este" (eastern plains, into the Merín Lake basin), where the southernmost populations of $C$. latirostris are found. These areas in southeastern Uruguay include the largest wetlands in the country, with important areas of rice production surrounding the Merín Lake. The wide variety of lothic and lenthic habitats (lagoons, rivers, creeks, streams, marshes, artificial ponds) colonized by $C$. latirostris in the above mentioned landscape units agrees with authors that consider this caiman as a habitat generalist (Yanosky 1990, Verdade 1998).

Several authors have suggested that illegal hunting and habitat destruction in Uruguay may have caused a severe decline on $C$. latirostris populations, which were undergoing risk of extinction in this country (Vaz-Ferreira 1956, 1971, Orejas-Miranda 1969, Talice 1971, Achaval 1977, 1997, Sierra et al. 1977). However, Medem (1983) stated that C. latirostris was never hunted in Uruguay on a commercial scale that may have been true at that time. Caiman sport hunting by non-rural people was detected in different areas, and seems to be directed mainly towards big adults and at a small scale. After a five-year period of surveys in northern Uruguay (1999-2003), trade of caiman meat or skins was not detected. Even caiman are killed by subsistence hunters, it seem not to be an important subsistence resource for rural people. Brazeiro (1973) reported hunting and consumption of Broad-snouted Caiman meat in Artigas. González (1987) also mentioned that a female was killed for this reason while she was protecting her nest. During this study it was observed that several caiman were killed sporadically by nutria (Myocastor coypus) and capybara (Hydrochoerus hydrochaeris) hunters in the Depts. of Cerro Largo, Rocha and Treinta y Tres (CP, pers. obs.)

The most important threat to C. latirostris, by far, is habitat destruction (Verdade 1998). Assessment of habitat availability and loss of natural areas inhabited by the Broad-snouted Caiman in Uruguay remains to be studied. Little is known about C. latirostris populations in eastern and central Uruguay or about the potential hazardous effects of pesticides used in agriculture. It has been reported that important wetlands have been impacted by agriculture practices in eastern part of the country (PROBIDES 1999). On the other hand, the construction of artificial impoundments as water reservoirs for agriculture and cattle in northern Uruguay created a new habitat that seems to have favored caiman (Borteiro et al. 2001, Borteiro 2005).

Sport hunters in northern Uruguay (mainly in the Dept. of Artigas) usually eat their kill as do subsistence hunters. However, hunters from eastern part of the country usually do not eat caiman meat. This difference is possibly because of cultural constraints as the relative importance of caiman (Caiman sp.) as food for non-indigenous rural people of Latin America is quite variable, being accepted by some communities but rejected by others (Ojasti 1993). Hunting pressure on Broad-snouted Caiman populations as a source of food is well known from Bolivia (Pacheco 1996), and Brazil (Brazaitis et al. 1990) where the species is sold as salted fish meat in local markets of the State of Alagoas (Verdade 2001). Non-shooting hunting methods of rural people in Uruguay, which include the use of hooks and baited sticks, are the same as those previously reported by Brazeiro (1973) for the Dept. of Artigas. Small baited bones are also used in Argentina (Walsh 1987).

If we consider previous localities where eggs and nests of $C$. latirostris were collected in Uruguay (Achaval and González 1983, VazFerreira and Achaval 1986, González 1987) and nests found during the present study, the species seems to breed in a wide area. Nesting habitats in northern Uruguay include riverine forests, artificial water bodies (cattle waterholes and agriculture impoundments), grasslands at the shoreline of creeks, and floating vegetation mats. These habitat types are almost the same as 
reported by Larriera (1995) for Santa Fe Province in Argentina. Available data indicate that the incubation period of this caiman species at the southern extent of its range is from midJanuary to late March. In the central regions of the species range, in the State of São Paulo, Brazil $\left(22^{\circ} \mathrm{S}\right)$, Verdade (1995) reported that captive females of $C$. latirostris nest from late October to mid-February, and that the hatching period extends from mid-February to mid April. Peak nesting occurred in January while peak hatching was in March. Similarly, Campos and Mourão (1995) in the State of Mato Grosso do Sul, Brazil $\left(20^{\circ} \mathrm{S}\right)$ estimated that the nesting period of $C$. latirostris in the wild occurs in late December and hatching in early March.

\section{Ackowledgements}

The authors wish to thank Sergio Ripoll and Miguel Silva for their invaluable participation in fieldwork, as well as CALNU, landowners and farm workers of Bella Unión. We are also grateful to all those people who enriched this work with important information, to María Cristina Machado and Juan Carlos Borteiro who provided a vehicle, and to Héctor Etcheverry for the boat. Luciano Verdade and Alejandro Larriera reviewed early versions of this manuscript and shared bibliography. Gustavo Pereira assisted in manuscript preparation, and Gustavo Speranza, Gustavo de Souza and José Manuel Venzal helped during field surveys. The suggestions made by Jaime Bertoluci and two anonymous referees greatly improved the manuscript. This work was partially funded by CSIC (Grant N 938/01), Universidad de la República, Montevideo. Surveys were done under División Fauna - MGAP Permits Nos. 1043/01, 417/03, and 195/06.

\section{References}

Achaval, F. 1977. Lista comentada de los reptiles que habitan en la zona de influencia de la Represa de Sal- to Grande. Pp. 173-181 in Seminario Sobre Medio Ambiente y Represas I. Facultad de Humanidades y Ciencias-OEA, Montevideo.

Achaval, F. 1980. El Yacaré. Boletín del Museo Nacional de Historia Natural de Montevideo 2: 5-6.

Achaval, F. 1997. Actualización sistemática y sinonímica de los reptiles del Uruguay con comentarios y distribución. Unpublished MSc. Dissertation. Facultad de Ciencias, Universidad de la República, Montevideo. 693 p.

Achaval, F. 2001. Actualización sistemática y mapas de distribución de los reptiles del Uruguay. 2001. Smithsonian Herpetological Information Service 129. $37 \mathrm{p}$.

Achaval, F. and J. C. González 1983. Sobre un nido con huevos de Caiman latirostris (Daudin, 1802) (Crocodylia, Alligatoridae) de la Isla Zapallo, Depto. de Artigas, Uruguay. 1983. Boletín de la Sociedad

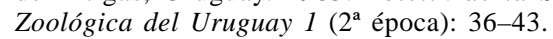

Achaval, F. and H. San Martín. 1983. Presencia del “yacaré de hocico ancho” Caiman latirostris (Daudin, 1801) (Crocodylia, Alligatoridae) en el Departamento de Rocha, Uruguay. 1983. Boletín de la Sociedad Zoológica del Uruguay 1 (2ª́poca): 11-15.

Anonymous. 1891. El Derecho de San Carlos, Año 1, 27 December 1891.

Bayliss, P. 1987. Survey methods and monitoring within crocodile management programmes. Pp. 157-175 in G. J. W. Webb, S. C. Manolis and J. Withehead (eds.), Wildlife Management: Crocodiles and Alligators. Surrey Beatty and Sons Pty. Ltd., Conservation Commission of the Northern Territory, Australia.

Borteiro, C., M. Tedros, F. Gutiérrez, F. Kolenc, G. Speranza, and J. P. Dragonetti. 2001. First survey of Caiman latirostris in northern Uruguay. Crocodile Specialist Group Newsletter 20: 28-31.

Borteiro, C. 2005. Abundancia, estructura poblacional y dieta de yacarés (Caiman latirostris: Crocodylia, Alligatoridae) en ambientes antrópicos del Departamento de Artigas, Uruguay. Unpublished MSc. Dissertation. Facultad de Ciencias, Universidad de la República, Montevideo. 79 p.

Brazaitis, P. 1973. The identification of living crocodilians. 1973. Zoologica N. Y. 58: 59-101.

Brazaitis, P., C. Yamashita, and C. A. Rebelo. 1990. A summary report of the South American caiman study. Phase I: Brazil. Pp. 110-115 in Crocodiles: Their Ecology, Management, and Conservation, IUCN-The World Conservation Union, Gland, Switzerland.

Brazeiro, C. 1973. Por Campos y Montes. Nueva Independencia, Montevideo. 158 p.

Brito del Pino, J. 1956. Diario de la Guerra del Brasil (Agosto de 1825-Noviembre de 1828). Montevideo. 
Campos, Z. and G. Mourão. 1995. Caiman latirostris (Broad-snouted caiman). Nesting. Herpetological Review 26: 203-204.

Chebez, J. C., T. Waller and E. Richard. 1994. Reptiles. Pp. 55-65 in J. C. Chebez (ed.). Los que se van. Especies argentinas en peligro. Albatros, Buenos Aires.

Diefenbach, O. C. 1979. Ampullarid gastropod: staple food of Caiman latirostris? Copeia 1979: 162-163.

Diefenbach, O. C. 1988. Thermal and feeding relations of Caiman latirostris (Crocodylia: Reptilia). Comparative Biochemistry and Physiology 89A: 149-155.

Evia, G., and E. Gudynas. 2000. Ecología del paisaje en Uruguay. DINAMA - AECI - Junta de Andalucía, Sevilla.173 p.

Freiberg, M. A. and A. Leitão de Carvalho. 1965. El Yacaré sudamericano Caiman latirostris (Daudin). Physis 25: 351-360.

González, T. U. 1987. Nidificación y nacimiento de Caiman latirostris latirostris "Yacaré de hocico ancho" (Daudin 1802). 1987. Comunicaciones de Estudios de Comportamiento en la Estación de Cría de Fauna Autóctona de Piriápolis- "Cerro Pan de Azúcar” 2: 1-16.

Larriera, A. 1995. Áreas de nidificación y momento óptimo de cosecha de huevos de Caiman latirostris en Santa Fe, Argentina. Pp. 221-232 in A. Larriera and L. M. Verdade (eds.), La Conservación y el Manejo de Caimanes y Cocodrilos de América Latina. Fundación Banco Bica, Santo Tomé, Santa Fe, Argentina.

Magnusson, W. E. 1982. Techniques of surveying for crocodilians. Pp. 389-403 in Crocodiles, Proceedings of the $5^{\text {th }}$ Working Meeting of the Crocodile Specialist Group, IUCN-The World Conservation Union, Gland, Switzerland.

Magnusson, W. E. 1983. Size estimates of crocodilians. Journal of Herpetology 17: 86-88.

Medem, F. 1983. Los Crocodylia de Sur América. II. Venezuela, Trinidad-Tobago, Guyana, Suriname, Guyana Francesa, Ecuador, Perú, Bolivia, Brasil, Paraguay, Argentina, Uruguay. Colciencias, Bogotá. $270 \mathrm{p}$.

Melo, M. T. Q. 2002. Dieta do Caiman latirostris no sul do Brasil. Pp. 119-125 in L. M. Verdade and A. Larriera (eds.), Conservação e Manejo de Jacarés e Crocodilos da América Latina II. ESALQ/USP, C. N. Editorial, Piracicaba.

Micucci, P. A. and T. Waller. 1995. Los yacarés en Argentina: hacia un aprovechamiento sustentable. Pp. 81112 in A. Larriera and L. M. Verdade (eds.), $L a$ Conservación y el Manejo de Caimanes y Cocodrilos de América Latina. Fundación Banco Bica, Santo Tomé, Santa Fe, Argentina.
Morato, S. A. 1991. Localidades de registro e distribuição geográfica de Caiman latirostris (Daudin, 1802) (Crocodylia: Alligatoridae) no Estado do Paraná, Brasil. Acta Biologica Leopoldensia 13: 93-104.

Ojasti, J. 1993. Utilización de la Fauna Silvestre en América Latina. FAO, Guía Conservación 25, Roma. 248 p.

Orejas-Miranda, B. R. 1969. Reptiles. Pp. 41-68 in M. A. Klappenbach and B. R. Orejas-Miranda (Eds.), Anfibios y Reptiles. Nuestra Tierra, Montevideo.

Pacheco, L. F. 1996. Plan de Acción para los caimanes de Bolivia. Ecología en Bolivia 27: 43-53.

Piña, C., A. Imhof, N. Frutos, M. Medina, and A. Larriera. 2002. Tamaño de postura y medidas de huevos de Caiman latirostris en las Provincias de Santa Fe y Entre Ríos. Pp. 127-134 in L. M. Verdade and A. Larriera (eds.), Conservação e Manejo de Jacarés e Crocodilos da América Latina II. ESALQ/USP, C. N. Editorial, Piracicaba.

Praderi, R. and J. Vivo. 1975. Ríos y Lagunas. Nuestra Tierra, Montevideo. 68 p.

PROBIDES (Proyecto Biodiversidad de los Humedales del Este). 1999. Plan Director. Reserva de Biosfera Bañados del Este, Rocha, Uruguay. 159 p.

PROBIDES (Proyecto Biodiversidad de los Humedales del Este). 2001. Evaluaciones Ecológicas Rápidas aplicadas a la Reserva de Biosfera Bañados del Este. (Serie Documentos de Trabajo). 64 p.

Ross, J. P. (ed.). 1998. Crocodiles: Status Survey and Conservation Action Plan. $2^{\text {nd }}$ ed. IUCN/SSC, Crocodile Specialist Group. URL: http://www.flmnh. ufl.edu/natsci/herpetology/act-plan/plan1998a.htm. (Captured on 13 October 2005).

Sierra, B. H. Osorio, A. Langguth, J. Soriano, E. Maciel, O. Mora, R. Ayup, A. Lombardo, E. Palerm, J. González, and F. Achaval. 1977. Ecosistemas afectados por la represa de Salto Grande. Pp. 89-105 in Seminario Sobre Medio Ambiente y Represas 1. Facultad de Humanidades y Ciencias-OEA, Montevideo.

Sill, J. 1968. The Zoogeography of the Crocodylia. Copeia 1968: 76-88.

Talice, R. V. 1971. Zoogeografía Regional. Pp. 30-64 in R. V. Talice and J. Chebataroff (Eds.), Geografía de la Vida. Nuestra Tierra, Montevideo.

Vaz-Ferreira, R. 1956. Conservación de la Fauna Indígena y de los Recursos Naturales Animales. Ministerio de Ganadería y Agricultura-Comisión Nacional Protectora de la Fauna Indígena, Montevideo. 63 p.

Vaz-Ferreira, R. 1971. Fauna: conservación y recursos. Nuestra Tierra, Montevideo. 60 p.

Vaz-Ferreira, R. and B. Sierra. 1960. Notas sobre Reptiles 
del Uruguay. Revista de la Facultad de Humanidades y Ciencias 18: 133-206.

Vaz-Ferreira, R. and F. Achaval. 1986. Nidificación y nacimiento de Caiman latirostris latirostris (Daudin 1802). Facultad de Humanidades y Ciencias, Universidad de la República, Montevideo. 16 p.

Velasco, A. and J. Ayarzagüena. 1995. Situación actual de las poblaciones de baba (Caiman crocodilus) sometidas a aprovechamiento comercial en los Llanos Venezolanos. Publicación de la Asociación Amigos de Doñana 5: 1-70.

Venturino, J. J. 1994. Distribución, estado de las poblaciones y manejo de Caiman latirostris en la Provincia de Entre Ríos, Argentina. Pp. 31-39 in A. Larriera, A. Imhof, M. C. von Finck, A. L. Costa and S. C. Tourn (eds.), Memorias del IV Workshop sobre conservación y manejo del yacaré overo (Caiman latirostris). "La Región”-Fundación Banco Bica-Santo Tomé, Santa Fe, Argentina.

Verdade, L. M. 1995. Biologia reprodutiva do jacaré-depapo-amarelo (Caiman latirostris) em São Paulo, Brasil. Pp. 57-79 in A. Larriera and L. M. Verdade (eds.), La Conservación y el Manejo de Caimanes y Cocodrilos de América Latina. Fundación Banco Bica, Santo Tomé, Santa Fe, Argentina.

Verdade, L. M. 1998. Caiman latirostris. Pp. 18-20 in J. P. Ross (ed.), Crocodiles: Status Survey and Conserva- tion Action Plan. IUCN, Gland, Switzerland, $2^{\text {nd }}$ ed.

Verdade, L. M. 2001. The São Francisco River "Codfish": the northernmost wild populations of the Broadsnouted caiman (Caiman latirostris). Crocodile Specialist Group Newsletter 20: 80-82.

Verdade, L. M., Zucoloto, R. B. and L. L. Coutinho. 2002. Microgeographic variation in Caiman latirostris. Journal of Experimental Zoology 294: 387-396.

Waller, T. and P. A. Micucci. 1994. Situación del género Caiman en Argentina. Apuntes sobre su distribución, situación poblacional y comercio histórico. Pp. 40-49 in A. Larriera, A. Imhof, M. C. von Finck, A. L. Costa, and S. C. Tourn (eds.), Memorias del IV Workshop sobre conservación y manejo del yacaré overo (Caiman latirostris). “La Región”, Fundación Banco Bica, Santo Tomé, Santa Fe, Argentina.

Walsh, B. 1987. Crocodile capture methods used in the Northern Territory of Australia. Pp. 249-252 in G. J. W. Webb, S. C. Manolis and J. Whitehead (eds.), Wildlife Management: Crocodiles and Alligators, Surrey Beatty and Sons Pty. Ltd., Conservation Commission of the Northern Territory, Australia.

Yanosky, A. A. 1990. Histoire naturelle du Caiman à museau large (Caiman latirostris), un Alligatorinè mal connu (1). Revue Française d'Aquariologie et Herpetologie 17: 19-31.

Appendix I. Geographic Coordinates of Localities Mentioned in the Text

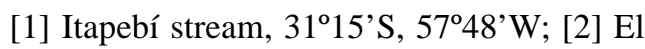

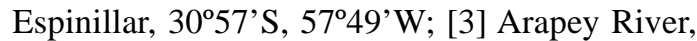
3057'S, 57²4'W; [4] Colonia Lavalleja, $31^{\circ} 06^{\prime} \mathrm{S}, 57^{\circ} 01^{\prime} \mathrm{W}$; [5] Yacuy stream, 3046’

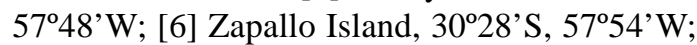

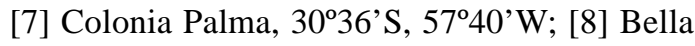
Unión, $30^{\circ} 15^{\prime} \mathrm{S}, 5^{\circ} 35^{\prime} \mathrm{W}$; [9] Yucutujá stream,

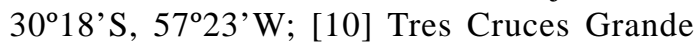
stream, $30^{\circ} 17^{\prime} \mathrm{S}, 5^{\circ} 11^{\prime} \mathrm{W}$; [11] Yacaré stream, $30^{\circ} 07^{\prime} \mathrm{S}, 5^{\circ} 03^{\prime} \mathrm{W}$; [12] Yacot stream, 3007' S,

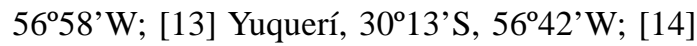
Cuaró Chico stream, 30³6’'S, 56 ${ }^{\circ} 57^{\prime} \mathrm{W}$; [15] Tres Cruces Chico stream, 3040'S, 56 $33^{\circ} \mathrm{W}$; [16] Pueblo Ansina, 31 $54^{\prime} \mathrm{S}, 5^{\circ} 28^{\prime} \mathrm{W}$; [17] Leoncho stream, 32 ${ }^{\circ} 55^{\prime} \mathrm{S}, 5^{\circ} 58^{\prime} \mathrm{W}$; [18] Estero

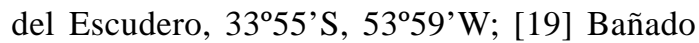
de Santa Teresa, $33^{\circ} 45^{\prime}$ S, $53^{\circ} 26^{\prime} \mathrm{W}$; [20] La

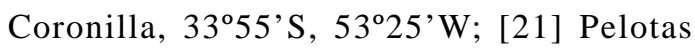

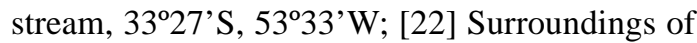

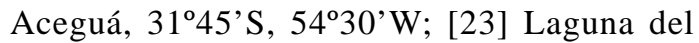

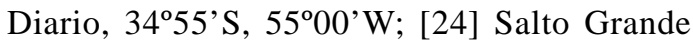

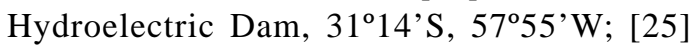
Itacumbú stream, $30^{\circ} 20^{\prime} \mathrm{S}, 5^{\circ} 34^{\prime} \mathrm{W}$; [26] CALPICA $30^{\circ} 25^{\prime} \mathrm{S}, 5^{\circ} 40^{\prime} \mathrm{W}$; [27] Lenguazo stream basin, $30^{\circ} 25^{\prime} \mathrm{S}, 57^{\circ} 41^{\prime} \mathrm{W}$; [28] COPCABU, $30^{\circ} 27^{\prime} \mathrm{S}, 5^{\circ} 44^{\prime} \mathrm{W}$; [29] Lagreca

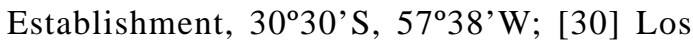

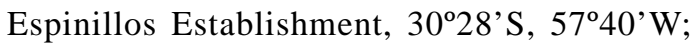

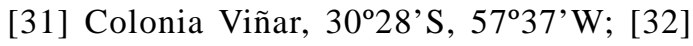
Falso Mandiyú stream, 30³4’S, 57²0’W; [33] Tigre stream, $30^{\circ} 34^{\prime} \mathrm{S}, 5^{\circ} 47^{\prime} \mathrm{W}$; [34] Guaviyú

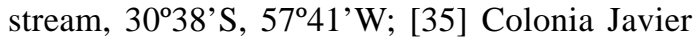
de Viana, 30² $4^{\prime}$ S, 56 $45^{\circ} \mathrm{W}$; [36] Pay Paso Establishment, $30^{\circ} 16^{\prime} \mathrm{S}, 5^{\circ} 25^{\prime} \mathrm{W}$; [37] Tierras 


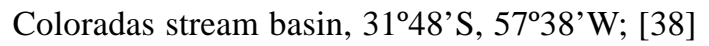

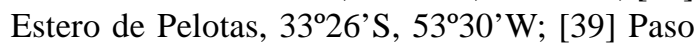

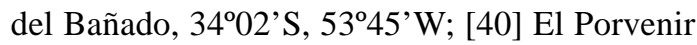
Establishment, $33^{\circ} 55^{\prime} \mathrm{S}, 5^{\circ} 25^{\prime} \mathrm{W}$; [41]

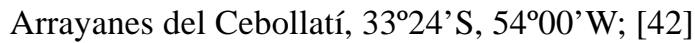
Kiosco Tacuarí, 3245'S, 53³8'W; [43] Tacuarí River, 3245'S, 5318'W; [44] Yucutujá Miní

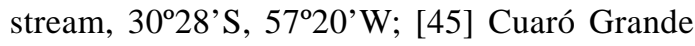
stream, $30^{\circ} 27^{\prime} \mathrm{S}, 57^{\circ} 07^{\prime} \mathrm{W}$; [46] Yacuy stream, $30^{\circ} 45^{\prime} \mathrm{S}, 5^{\circ} 23^{\prime} \mathrm{W}$; [47] Mandiyú stream 30³2'S, 57²40'W; [48] Balneario Laguna

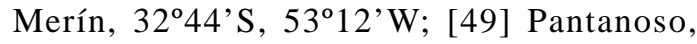

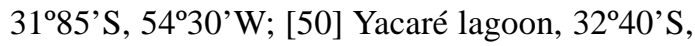
533' W; [51] Fraile Muerto, 32 $36^{\circ}$ 's, $54^{\circ} 34^{\prime} \mathrm{W}$; [52] Surroundings of José Pedro

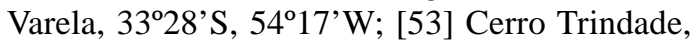
$30^{\circ} 57^{\prime} \mathrm{S}, 5^{\circ} 27^{\prime} \mathrm{W}$; [54] Bañados de India

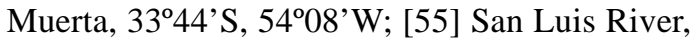
$33^{\circ} 35^{\prime} \mathrm{S}, 53^{\circ} 40^{\prime} \mathrm{W}$; [56] Km 324 of Route 14, $33^{\circ} 36^{\prime} \mathrm{S}, 5^{\circ} 46^{\prime} \mathrm{W}$; [57] San Miguel stream,

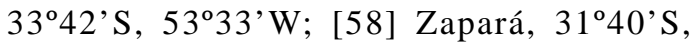

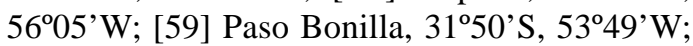
[60] Las Veras, $32^{\circ} 05^{\prime} \mathrm{S}, 5^{\circ} 34^{\prime} \mathrm{W}$; [61] Tacuarí

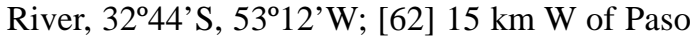
del Dragón, 3245'S, 5355’W; [63] Zapata

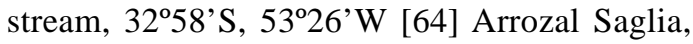
$33^{\circ} 10^{\prime} \mathrm{S}, 53^{\circ} 35^{\prime} \mathrm{W}$. 